\title{
5. The Rudd administration and the Senate: business as usual ${ }^{1}$
}

\author{
HARRY EVANS
}

\section{Introduction}

Like most federal governments, the Rudd administration did not possess a party majority in the Senate. This is usually seen as a problem for governments - a source of trouble and frustration, giving rise to the possibility of a dissolution of both Houses under the deadlock-resolving provisions in Section 57 of the Constitution, if the Senate rejects, unacceptably amends or fails to pass government legislation within the terms of that section. Nowadays, a party majority in the Senate is taken to mean control of the chamber because of the strength of party discipline. In the past, however, non-Labor governments particularly could not always control their senators so that even with a party majority governments could find themselves in difficulties in the Senate.

A case can be made that lack of control of the Senate is good for governments: it compels them to justify their legislative proposals rather than ram them through (legislation is often improved even by amendments moved by opponents); it encourages the seeking of broader support for policies and the compromise that often improves programs; it imposes greater accountability and thereby helps avoid mistakes and lapses in propriety and legality; and it counters the temptation to legislate highly partisan measures ultimately harmful to their authors (the now leading example being the last Howard government's workplace relations legislation). Discussion of senate/government relations, however, invariably concentrates on the negatives.

Of all governments, the Rudd administration had the least justification for any claim that the Senate was the cause of its problems. Admittedly, the numbers

\footnotetext{
1 Information in this chapter is drawn from publications by the Department of the Senate, principally Business of the Senate and Work of Committees, which are cumulated annually and which can be found on that department's web site (<www.aph.gov.au/Senate $>$ ). Analysis and commentary are, of course, the responsibility of the author.
} 
in the Senate were particularly difficult for this government. For the first eight months of its life, it had to make do with the Coalition parties' senate majority of one left over from the last Howard administration, until the Senate places turned over in accordance with that house's fixed term. That situation was not a serious disadvantage, as it gave the incoming ministry breathing space to formulate its ambitious agenda. After 1 July 2008, if the Coalition opposed a government measure, the proposal had to gain the support of all seven minorparty senators - five Greens, one Family First Party and one independent - to form a majority to be carried. The loss of only one of those votes, where the Coalition parties were opposed, was fatal to any government proposal under the constitutional provision whereby equally divided votes in the Senate negatives the motion before the chamber, while the loss of two meant that any nongovernment measure would have a majority.

There are four areas in which a non-government majority in the Senate may challenge the government: the amendment or rejection of government legislation; the conduct of inquiries into matters that might expose government weaknesses; Senate demands for information, particularly as a condition of passing legislation; and disallowance of delegated legislation. The Senate may express its disapproval of government activities in extreme cases by censure motions, but these have no effect other than to draw attention to alleged failings.

\section{Legislation}

The first major item on the new government's agenda was the replacement of the Howard workplace relations legislation. This went relatively smoothly, as the minor parties had opposed the key elements of that legislation in the first place. Subsequently, the course became more difficult, due mainly to the complexity of legislation, particularly for the emissions trading scheme.

The figures for government bills rejected by the Senate always convey an impression of moderation, as the overwhelming majority are passed. In 2008, 11 bills were rejected compared with 159 passed; in 2009, there were 15 rejected and 136 passed; and in 2010 only three - all hangovers from 2009-were rejected and 114 passed. In many cases, multiple bills contain one measure; the emissions trading scheme consisted of 11 bills, accounting for the high number of rejections in 2009 .

These raw statistics give no clue of the importance of the measures, and some major government proposals were rejected. The most significant was the emissions trading scheme-twice rejected in 2009, thereby providing the government with a 'trigger' for a double dissolution by which it could seek a more friendly senate from the electorate. Any claim of obstruction there, 
however, was undermined by the announcement in 2010 that the legislation would be postponed, largely because of lack of international cooperation, which was one of the grounds on which the Coalition parties voted against it. Other measures providing triggers related to changes to private health insurance.

Some bills rejected were later passed with or without senate amendments, including those relating to the government's nation-building expenditures, the luxury car tax, government borrowings by the issue of bonds, household stimulus payments, cost recovery in the Pharmaceutical Benefits Scheme, the establishment of Safe Work Australia, income support for students and the Medicare levy surcharge. Some bills rejected were not presented again, or not in a form allowing the achievement of a trigger, which could lead observers to question the government's commitment to them. Those not presented again included a bill to establish the Australian Business Investment Partnership as part of the government's anti-recession program and another to set up a national monitor on fuel prices.

Some major bills were passed with senate amendments accepted by the government - notably those concerning income support for students in 2009 and paid parental leave in 2010. The latter came to be regarded as virtually the only big legislative achievement of the government. As its term went on, the Rudd ministry showed a greater readiness to accept amendments originating in the Senate, including those suggested in senate committee reports, which were often adopted before the bills in question reached the Senate. This procedure was used by previous administrations. There were no serious new senate/government disagreements over legislation in 2010. The government was learning how to manage the Senate; and the learning process usually takes most of a first term.

That the Rudd government was let off lightly with its legislation, apart from the problematical emissions trading scheme, can be demonstrated by a comparison with the first three Howard administrations, which did not have senate majorities. Those governments built up 'storehouses' of double-dissolution triggers, which were never used, all relating to major government policies, so that those policies could simply not be enacted. In the 1996-98 Parliament, there were four bills providing triggers, relating mainly to workplace relations - the most significant and contentious issue throughout the Howard era. In the 1998-2001 Parliament, that subject appeared again as the sole trigger. In 2001-04, there were sevenrelating to workplace relations again, the full sale of Telstra, border protection, disability entitlements and protection of small businesses under the trade practices regime. Many other bills were passed with senate amendments the government would rather not have had, indicating a pragmatic approach of taking what it could get through the Senate in some areas while refusing to compromise on the 'big-ticket' items. 


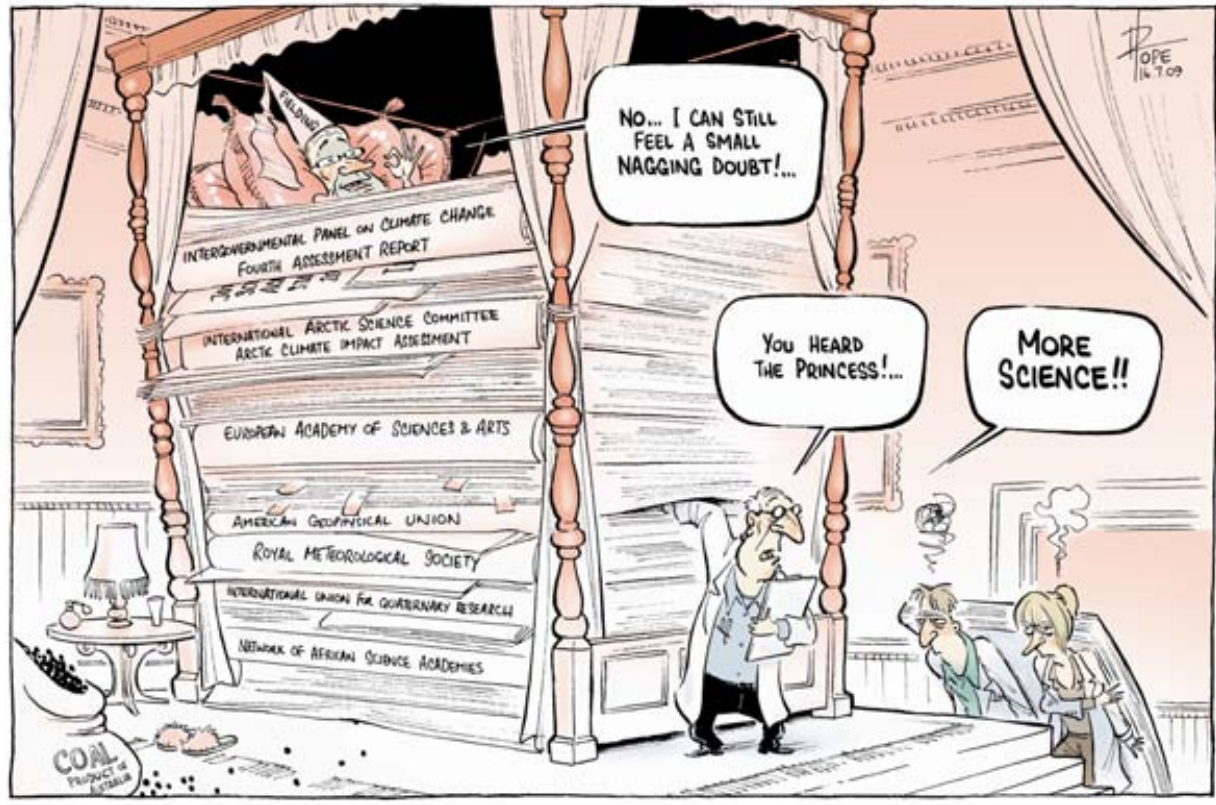

Complaints by Rudd ministers about 'senate obstruction' were muted compared with those of the Howard era, and this accurately reflected the real situation.

Source: David Pope, The Public Sector Informant, June 2009

\section{Inquiries}

Governments lacking senate majorities have always had to cope with senate inquiries that exposed their failings and delayed their measures. As already suggested, this traditional parliamentary activity is often beneficial to a government by keeping the ministry on its mettle, but governments habitually resist it. Inquiries are usually conducted through committees, and the public hearings have an immediate impact, reinforced by the subsequent committee reports, as they allow those with any kind of interest in a matter to critique the relevant government measures.

It is now accepted, even for the most part by governments, that all complex or contentious government legislation, and all major government policies and programs, will be referred to senate committees for public hearings. In this regard the experience of the Rudd government was not unusual, but its significant policies and proposals were very complex and contentious, and committee hearings were bound to expose difficulties. All of the forms of senate 
committee inquiry-hearings on bills, hearings on terms of reference referred by the Senate to both standing and select committees and estimates hearingswere used to scrutinise those policies and proposals.

Standing committee hearings on matters referred by the Senate included those on the government's response to the global financial crisis, the financial guarantees given by the government and its stimulus expenditure, Murray-Darling Basin management and water policy generally, and the tender process for employment services contracts. Select committees, which are appointed for specific inquiries into particular matters, scrutinised the proposed national broadband network, climate policy and state government financial management (that is, the handling of commonwealth money by state Labor governments). While these kinds of inquiries inform the public, they also compel the government to explain in detail what it is doing and why. In all of these areas, the Rudd government had considerable explaining to do.

This experience was not different from that of the Howard governments that lacked a senate majority. Every major proposal of those administrations - such as the GST and the workplace relations overhaul-was subjected to the most intense committee scrutiny. Inquiries causing particular difficulties for the government included: those into tax reform (spread over several committees); the operation of the Tax Office; unfair dismissal law; funding of government schools; cuts to childcare funding; global warming policy; the 'children overboard' affair; government advertising, which became a major electoral issue with the huge expenditure on advertising the WorkChoices legislation; and the regional partnerships program - the inquiry into which led to a devastating Auditor-General's report, released just before the 2007 election, with significant damage to the government. So the Howard ministries were vexed by senate inquiries no less than that of Rudd, and probably more so.

Governments now spend a great deal of time and energy (and money) attempting to control the information flow, to ensure as far as possible that the information reaching the public is favourable to them or at least has a favourable 'spin'. Senate inquiries, which the government cannot control, break down that information management and give the public a different and fuller picture. Shortly before the fall of Prime Minister Rudd, a senate hearing revealed that the Department of Climate Change and Energy Efficiency was not told in advance of the decision to postpone the emissions trading scheme, making that decision appear even more erratic. 
The Rudd Government

\section{Demands for information}

The Senate makes demands for information by means of orders for the production of documents - an ancient procedure whereby ministers are ordered to lay before the Senate, and thereby make public, specified documents or those relating to a particular matter. The passage of one of these orders-almost always relating to a matter of some contention-usually indicates that the non-government parties think that the government is hiding something. Often the orders refer to information refused to a committee. Mostly governments comply with the orders, but sometimes they refuse, which raises suspicions that there really is something to hide. A senate resolution requires that a refusal be accompanied by a recognised public interest ground. There is a range of legitimate public interest grounds, such as prejudice to legal proceedings and damage to international relations, but it is up to the Senate to decide whether a ground is justifiably raised in the particular case. If the Senate is not satisfied, it may impose procedural penalties on the government. The most serious penalty would be a refusal to pass government legislation.

In that regard the Rudd government soon found itself in difficulties. The Senate required the production of information on the economic modelling of the emissions trading scheme and on the proposed national broadband network. The government refused, initially at least, mainly on the ground of commercial confidentiality - an excuse now regarded as slippery because of past misuse. This provided the Senate majority with a seemingly reasonable basis for not passing the relevant legislation. The emissions trading legislation was rejected in 2009 and a motion was passed declaring that legislation for the national broadband network would not be considered until the required information was produced.

Other orders in 2008 and 2009 related to subjects that caused great difficulties for the government, such as the green loans, the home insulation program and the school building scheme. In 2008, there were nine orders eliciting five government refusals; in 2009, there were 32 orders with seven government refusals. The 22 orders passed in 2010 provide a check list of the accumulated issues causing the government problems: government advertising, particularly when the government exempted itself from its own rules with respect to the proposed mining tax, after claiming to have cured the advertising abuses of the Howard era; the proposed national broadband network again; the home insulation program again; green loans again; asylum-seekers; taxation reform; and many others.

There were several claims by the government that documents should not be produced, with some of the usual suspects - the difficult issues - appearing 
again. Not all of those claims were based on coherent public interest immunity grounds - a concept that the government and its public servants still do not fully understand.

In 2008, when the Coalition parties suddenly rediscovered parliamentary accountability, orders were passed requiring the publication of lists of government appointments and grants. There could hardly be any argument against this and the government complied. These orders, like an earlier, preRudd one on government contracts, are of continuing effect so will operate as an additional accountability measure on future governments.

Again, a comparison with the Howard administrations suggests that the Rudd government was treated lightly. In 1996-98, there were 48 orders for documents, five of which were not complied with by the government; in 1998-2001, there were 56 orders and 15 not complied with; and in 2002-04, there were 89 orders of which 46 were not complied with. The figures indicate a growing resistance by the Howard ministries to senate demands for information. In several cases, initial refusals to produce the documents in question were followed by capitulation after pressure was applied, particularly by way of committee hearings. The orders often related to matters causing severe difficulties for the government, such as the waterfront affair of 1998, proposed welfare changes in 1999, the magnetic resonance imaging machine affair of 1999-2000 and higher education funding in 1998 and 2002-03. Two customs and excise tariff bills were deferred until relevant information was produced. Frequent claims of commercial confidentiality in relation to government contracts led to a senate order for all contracts to be listed on the Internet, with any claims of confidentiality to be explicitly stated and subject to scrutiny by the Auditor-General; after initial resistance, this order has since been complied with. Nothing in the Rudd era equals this record of conflict between the Senate and the government over the disclosure of information.

\section{Disallowance of delegated legislation}

Government policies are frequently given effect by delegated legislationinstruments made by ministers under authorisations contained in statutes. Such instruments are subject to disallowance by either house of the Parliament, which means that the Senate has the opportunity to veto the policies contained in them, just as it has the power to veto proposed primary legislation contained in bills.

The Rudd government did not promulgate many contentious statutory instruments, probably because its major plans required primary legislation. In 2008, the Senate disallowed only three instruments, involving government 
policies relating to road user charges, dental services and higher education grants. In 2009, seven disallowance motions were carried, three of which related to significant policy issues: construction industry regulation, export control charges and increased fees for cataract surgery. The last-named issue, which carried over into 2010, led to a long battle between the Senate majority and the government, with the Senate disallowing successive instruments and the government seeking ways to bypass the disallowance procedure; the government eventually compromised on the matter. In 2010, two instruments were disallowed, relating to aviation security and therapeutic goods.

By way of comparison, during the three Howard administrations that lacked senate majorities, there were 27 instruments disallowed by the Senate, many involving major policy matters, so there was nothing unusual about the Rudd government's treatment in this area.

\section{Censure motions}

As already noted, censures of ministers or the government collectively by the Senate have no immediate effect, but they provide a measure of the degree of conflict and difficulty experienced by the government with the Senate.

During the life of the Rudd government only one censure motion was passed by the Senate, relating to the delivery of climate change policies, particularly the roof insulation program and the green loans scheme, which must rate as some of the greatest public administration failures ever-well deserving of parliamentary disquiet.

During the first three Howard administrations, ministers were censured on 11 occasions, for offences ranging from failures to produce information in response to senate orders and administrative breakdowns to participation in the Iraq war on false or undisclosed grounds.

If censure motions were to be regarded as the sole index of senate/government conflict, it would be taken that the Rudd government led a relatively peaceful life in the Senate.

\section{A minor factor}

Defeats and difficulties in the Senate are therefore only a relatively minor part of the story of the Rudd administration. The defeat that stands out is the rejection of the emissions trading scheme-declared by the Prime Minister to be his greatest moral issue. That episode, however, is overshadowed by the 
subsequent announcement that the project would be deferred. The form of that announcement was puzzling. The government could simply have stated that it was still committed to the scheme but would wait until the electors gave it a more favourable senate. The adverse reaction to the announcement was speedily followed by the overthrow of the Prime Minister by his party. That is the event that will occupy historians of the period. In the history of the Senate, the Rudd era will be seen as exhibiting a normal pattern of activity of that house: 'business as usual.'

Harry Evans was Clerk of the Senate from 1988 to 2009. 